\title{
REVIEW
}

\section{Clinical review: Adiponectin biology and its role in inflammation and critical illness}

\author{
Katherine Robinson*1, John Prins ${ }^{2}$ and Bala Venkatesh ${ }^{3,4}$
}

\begin{abstract}
Adiponectin is an adipokine first described just over a decade ago. Produced almost exclusively by adipocytes, adiponectin circulates in high concentrations in human plasma. Research into this hormone has revealed it to have insulin-sensitizing, anti-inflammatory and cardioprotective roles. This review discusses the history, biology and physiological role of adiponectin and explores its role in disease, with specific focus on adiponectin in inflammation and sepsis. It appears that an inverse relationship exists between adiponectin and inflammatory cytokines. Low levels of adiponectin have been found in critically ill patients, although data are limited in human subjects at this stage. The role of adiponectin in systemic inflammation and critical illness is not well defined. Early data suggest that plasma levels of adiponectin are decreased in critical illness. Whether this is a result of the disease process itself or whether patients with lower levels of this hormone are more susceptible to developing a critical illness is not known. This observation of lower adiponectin levels then raises the possibility of therapeutic options to increase circulating adiponectin levels. The various options for modulation of serum adiponectin (recombinant adiponectin, thiazolidinediones) are discussed.
\end{abstract}

\section{Introduction}

It is now known that adipose tissue is a dynamic endocrine organ in its own right, secreting a number of biologically active proteins, also known as adipokines [1]. One of these adipokines, adiponectin, has been recognised to play a major role in the pathogenesis of the metabolic syndrome. In recent years, its role in the

*Correspondence: katherine.robinson2@uqconnect.edu.au 'Intensive Care Unit, Wesley Hospital, 451 Coronation Drive, Auchenflower, Brisbane, Queensland, Australia

Full list of author information is available at the end of the article modulation of inflammation has become increasingly apparent. There has therefore been a spate of research examining its role in critical illness and sepsis. In this review we will discuss the biology of adiponectin and its physiological role, with a predominant emphasis on its role in inflammation and critical illness.

\section{The secretory function of adipose tissue}

The source of adipokines is either the adipocytes themselves or the stromal vascular fraction within adipose tissue, comprising preadipocytes, endothelial cells, fibroblasts, leukocytes and macrophages [1]. Resident stromal macrophages are a source of IL-10 and arginase. However, 'classically activated' macrophages recruited from the circulation to obese adipose tissue secrete the pro-inflammatory cytokines TNF- $\alpha$, inducible nitric oxide synthase, and IL-6. Adipocytes are responsible for the production of adiponectin, leptin, angiotensinogen and retinol-binding protein. Some adipokines, including monocyte chemoattractant protein-1 and apelin, are produced by both fractions $[1,2]$.

\section{Adiponectin}

Adiponectin is a protein produced and secreted almost exclusively by adipocytes [3]. First described over a decade ago, the interest in the biology of adiponectin was spurred by the discovery of measurable concentrations in plasma, its structural resemblance to complement factor $\mathrm{C} 1 \mathrm{q}$ and the consistent finding of decreased levels in obesity [4]. Adiponectin circulates in high concentrations in healthy adults and mice, accounting for $0.01 \%$ of total plasma protein and its plasma levels are a thousand times that of leptin [5]. Circulating levels of adiponectin range between 2 and $30 \mu \mathrm{g} / \mathrm{ml}$ in humans $[4,6]$ and are generally higher in females than males [7]. This sexual dimorphism has been attributed to the effect of testosterone on adiponectin secretion [8].

The gene encoding human adiponectin has been mapped to chromosome 3q27 [9]. In serum, adiponectin exists as three main forms: trimers, hexamers and highmolecular weight (HMW) multimers. To create these forms, a number of post-translational modifications are required (Figure 1). 


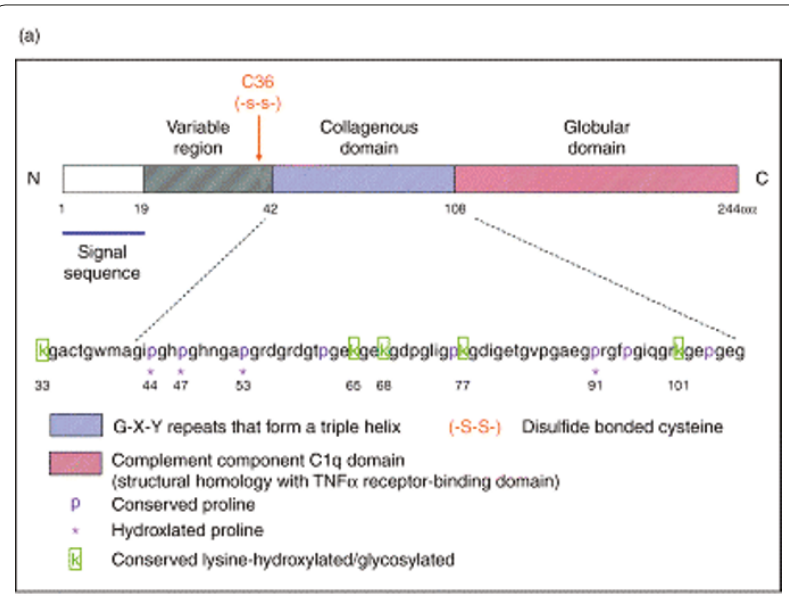

(b)
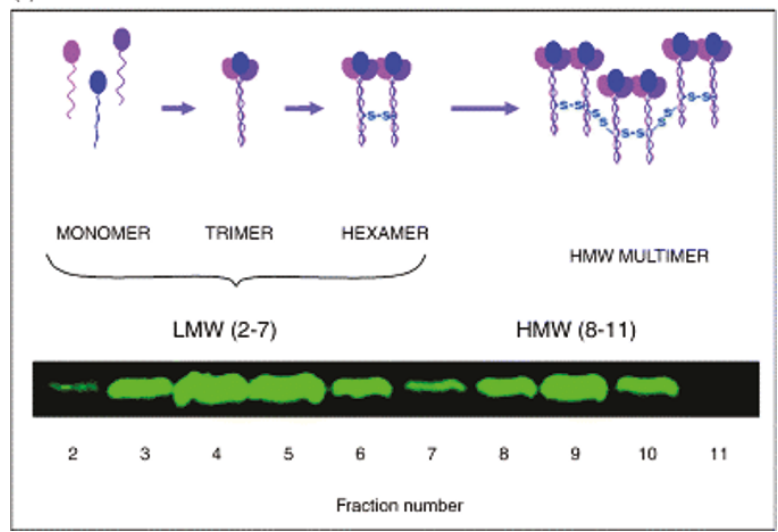

Figure 1. The structure and multimerization of adiponectin. (a) The domain structure of human adiponectin. (b) Adiponectin multimerization and analysis by velocity sedimentation. Separation of low-molecular weight (LMW) and high-molecular weight (HMW) multimers was performed by centrifugation on a 5 to $20 \%$ sucrose density gradient. Fractions 2 to 7 of the gradient contain the LMW multimers, while the HMW multimers are found in fractions 8 to 11 . Reproduced from Whitehead JP and colleagues [5].

This complex process and the cellular machinery involved in the secretion of adiponectin from adipocytes are well-described in several excellent reviews $[10,11]$. Murine studies show the half-life of circulating adiponectin to be 75 minutes with clearance mediated by the liver. HMW adiponectin has the slowest plasma clearance rate and serum levels remain fairly constant, despite rapid turnover [12]. There is evidence of elevated levels of adiponectin in chronic kidney disease and reduced clearance rates have been observed in animal models of end-stage renal disease [13]. A reduction in serum adiponectin has been observed after renal transplantation in humans, suggesting a possible role for the kidney in adiponectin clearance [14].

Three adiponectin receptors, AdipoR1, AdipoR2 and T-cadherin, have been identified. AdipoR1 is ubiquitous, but is most abundantly expressed in skeletal muscle and is linked to activation of AMP-activated kinase (AMPK) pathways. AdipoR2 is most abundantly expressed in the liver and is associated with activation of peroxisome proliferator-activated receptor (PPAR)- $\alpha$ pathways $[15,16]$. A third receptor for adiponectin, T-cadherin, expressed on vascular endothelial cells and smooth muscle, is a receptor for hexameric and HMW adiponectin [17]. The activation of AdipoR1 and R2 results in increased hepatic and skeletal muscle fatty acid oxidation, increased skeletal muscle lactate production, reduced hepatic gluconeogenesis, increased cellular glucose uptake and inhibition of inflammation and oxidative stress $[18,19]$. Activation of T-cadherin is protective in vascular endothelial cells against oxidative stress-induced apoptosis [20] and is strongly expressed in regions of atherosclerosis [21].

\section{Adiponectin in health and disease}

The precise physiological role of adiponectin is unclear. Adiponectin does not seem to be essential for survival as knockout (KO) mice survive with minimal lethality [22]. In humans, adiponectin is an insulin-sensitizing, vascularprotective, anti-inflammatory protein $[4,23,24]$ associated with a more favourable lipoprotein subclass profile [2].

To date, most of our understanding of adiponectin has been in its association with metabolic and cardiovascular health. Hypoadiponectinaemia is associated with obesity, insulin resistance and type 2 diabetes [4,23,24], as well as atherosclerosis, hypertension and coronary artery disease [25]. Low circulating levels, particularly of the HMW component [26], are also a strong risk marker for the development of the metabolic syndrome and type 2 diabetes $[27,28]$ (Table 1 ).

Recently, several observations point to a potential role for adiponectin in a variety of inflammatory diseases. Elevated serum adiponectin levels have been found in association with systemic lupus erythematosus [29], cystic fibrosis [30], inflammatory bowel disease [31] and rheumatoid arthritis [32]. The significance of these findings is not yet understood. Whether the high adiponectin may be part of the protective response to the underlying inflammation, or those with low adiponectin (or those less able to increase adiponectin) may be more prone to inflammation, or the changes purely represent an epiphenomenon need further elucidation. In this context, its role in the inflammatory response of critical illness is further discussed below.

\section{Adiponectin in critical illness}

Adiponectin and acute inflammation

Adiponectin exerts an anti-inflammatory effect through activation of all three receptors. Several mechanisms have been suggested, including direct actions on inflammatory cells, actions on NF-kB, and interaction with TNF- $\alpha$. 


\section{Table 1. Physiological functions of adiponectin}

Enhanced insulin sensitivity
Increased muscle glucose uptake
Decreased hepatic gluconeogenesis
Increased lipid metabolism
Fatty acid oxidation in skeletal muscle and liver
VLDL catabolism in skeletal muscle with reduction in plasma triglycerides
Vascular protection
Preservation of endothelial cell function
Anti-atherogenic
Hepato-protective
? Protective against malignancy
Anti-inflammatory
Decreases TNF-a, IL-6, CRP
Regulation of inflammatory cell function
? Neutralises endotoxin

CRP, C-reactive protein; VLDL, very-low-density lipoprotein.

\section{Direct actions on inflammatory cells}

Peripheral blood mononuclear cells (monocytes, natural killer (NK) cells and T and B lymphocytes) express adiponectin receptors 1 and 2 [33].

Adiponectin inhibits the growth of myelomonocytic progenitors and the functioning of mature macrophages [34], suppresses macrophage-to-foam cell transformation [35], stimulates macrophage production of the antiinflammatory cytokine IL-10 [36], inhibits both TNF- $\alpha-$ induced monocyte adhesion and adhesion molecule (vascular cell adhesion molecule (VCAM)-1, E-selectin and intercellular adhesion molecule (ICAM)-1) surface expression on endothelial cells [37] and inhibits Toll-like receptor-mediated $\mathrm{NF}-\mathrm{kB}$ activation in macrophages [38]. Adiponectin also inhibits the production of reactive oxygen species in human neutrophils [39]. Though of unclear significance, leukocyte elastase produced by neutrophils and activated monocytes is able to cleave adiponectin, producing a fragment containing the globular domain of the adiponectin molecule [40].

Most of these data have been generated from bench studies and clear dose-response relationships have not been demonstrated. For example, Yokota and colleagues [34] used in vitro concentrations of 0 to $50 \mathrm{mcg} / \mathrm{ml}$ of adiponectin, which approximate circulating physiological concentrations. However, Magalang and colleagues [39] were able to demonstrate suppression of free radical formation at doses of 0.001 to $1 \mathrm{mcg} / \mathrm{ml}$, which are clearly well below the normal concentrations.

\section{Actions on NF-KB}

$\mathrm{NF}-\mathrm{kB}$, a key player in the inflammatory response, is involved in the regulation of cellular functions, including the stress response. The action of adiponectin on NF-kB pathways is complex, being both stimulatory and inhibitory.

Initially, higher order multimers of adiponectin were reported to activate NF- $\mathrm{kB}$ pathways in myocytes [41]. Activation of NF- $\mathrm{kB}$ pathways by adiponectin has also been observed in vascular endothelial cells [42] and fibroblasts [43], as well as hepatocytes [44], where NF-кB activation induces secretion of a protective chemokine. Counteracting the above evidence is the demonstration of an inhibitory effect of adiponectin on the NF- $\mathrm{kB}$ pathways. Adiponectin suppresses lipopolysaccharidase (LPS)induced NF- $\mathrm{kB}$ activation in adipocytes [45], suppresses TNF- $\alpha$-induced NF- $\kappa B$ pathways in endothelial cells [46] and inhibits NF- $\kappa \mathrm{B}$ pathways in macrophages [47].

Adiponectin is also able to regulate the cytotoxicity of NK cells. Adiponectin activates AMP-activated kinase pathways in NK cells, which, in turn, inhibit IL-2-induced $\mathrm{NF}-\mathrm{kB}$ activation. This results in the suppression of the IL-2-enhanced cytotoxic activity of NK cells without affecting basal NK cell cytotoxicity [48].

The importance of the dual nature of adiponectin effects on NF-kB is not clearly understood and raises questions about the timing and the significance of each of these effects. When it is stimulatory, what initiates the change to an inhibitory effect, and which signalling molecules trigger the change are not precisely understood [49].

\section{Interaction with TNF- $a$}

Adiponectin may play a role in the downregulation of inflammatory responses involving TNF- $\alpha$. An inverse relationship has been shown to exist between TNF- $\alpha$ and adiponectin $[50,51]$. This effect is bi-directional, that is, primary changes in TNF- $\alpha$ can influence adiponectin concentrations and vice versa. TNF- $\alpha$ suppresses the expression and secretion of adiponectin from murine and human adipocytes in cell cultures [52,53]. Conversely, primary alterations in adiponectin result in inverse correlation with TNF. Adiponectin $\mathrm{KO}$ mice show high levels of TNF- $\alpha$ mRNA in adipose tissue and high plasma TNF- $\alpha$ concentrations, with reversal of these changes seen following viral-mediated adiponectin expression in these mice [24]. Additionally, adiponectin strongly inhibits LPS-induced TNF- $\alpha$ gene expression in macrophages [34]

The inverse correlation demonstrated between adiponectin and TNF- $\alpha$ in cell cultures has not been consistently reproduced in human subjects. Keller and colleagues [54] induced endotoxaemia in 23 healthy humans. Following endotoxin injection, TNF- $\alpha$ and IL-6 levels increased; however, there was no significant change in the level of adiponectin. Anderson and colleagues [55] explored the relationship between acute inflammation and adipokines within a cohort of 20 healthy humans. 


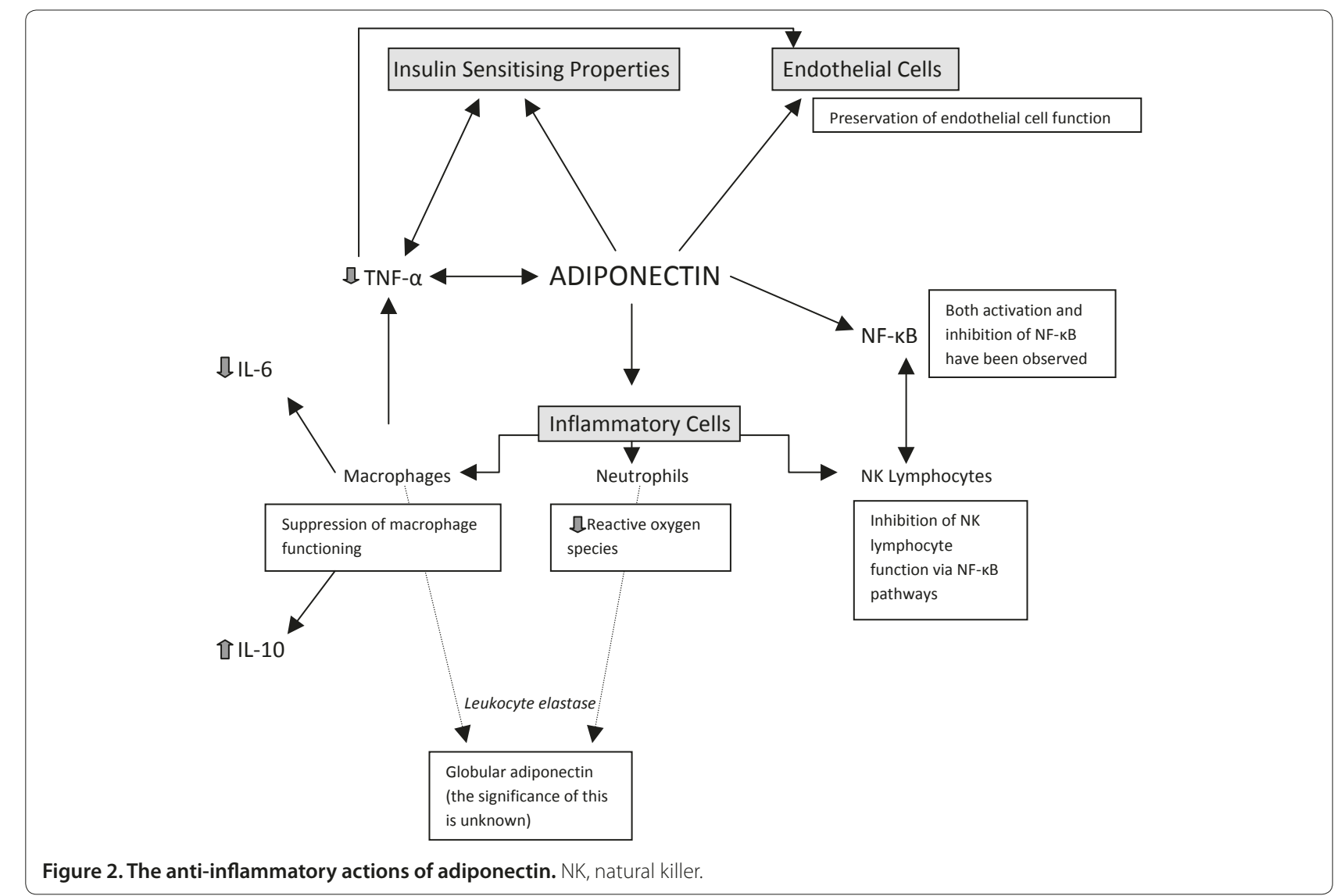

Endotoxaemia was associated with increases in whole blood leukocyte, monocyte and adipose tissue TNF- $\alpha$ and IL- 6 but with no significant changes in total plasma adiponectin or complex distribution. AdipoR1 and R2 receptor downregulation, however, was evident. Although adiponectin levels did not change, the downregulation of adiponectin receptors following endotoxaemia suggested attenuation of adiponectin's insulin sensitising and inflammatory signalling functions [55].

In animal models of sepsis, adiponectin deficiency is associated with a marked increase in inflammatory mediator status and exacerbation of hepatic injury $[56,57]$. In a recent study of 33 patients with severe sepsis or septic shock, a similar inverse correlation was demonstrated [58]. This consistent finding raises the possibility that modulation of adiponectin in sepsis may be a potential therapeutic target to attenuate the inflammatory response.

The anti-inflammatory properties of adiponectin are summarised in Figure 2.

\section{Adiponectin and sepsis}

The early observations that adiponectin antagonises the inflammatory effects of TNF- $\alpha$, negatively correlates with plasma TNF- $\alpha$ levels and shows structural homology to complement factor $\mathrm{C} 1 \mathrm{q}$ led researchers to further investigate the relationship between adiponectin and sepsis. Both animal and human data have been reported.

\section{Animal data}

In rats with induced polymicrobial sepsis, plasma adiponectin levels negatively correlated with plasma endotoxin and TNF- $\alpha$ levels [59]. Adiponectin was found to directly bind LPS and suppress limulus amoebocyte lysate in vitro. This animal model also provided the first evidence that the two adipokines, adiponectin and TNF- $\alpha$, inversely regulate each other's circulating concentration.

Uji and colleagues [56] reported that adiponectin $\mathrm{KO}$ mice were more susceptible to polymicrobial sepsis than wild-type mice. They investigated the role of adiponectin in sepsis using a murine model of caecal ligation and perforation (CLP). Adiponectin $\mathrm{KO}$ and wild-type mice were subjected to CLP and the effects of rosiglitazone (a PPAR- $\gamma$ agonist) on survival were investigated. Although the authors concluded that adiponectin deficiency was associated with excess mortality and high cytokine levels, several questions were raised by the study. Plasma endotoxin and IL-6 levels in adiponectin KO mice after CLP were significantly higher than in wild-type mice only at 24 hours, not earlier. Moreover, other pharmacodynamic 
Table 2. Data compiled from animal studies in inflammation and sepsis

\begin{tabular}{|c|c|c|}
\hline Year & Reference & Data \\
\hline 2002 & Maeda et al. [24] & Delayed clearance of free fatty acids and increased plasma TNF-a in adiponectin KO mice \\
\hline 2006 & Tsuchihashi et al. [59] & Rat CLP model shows that adiponectin negatively correlates with plasma endotoxin and TNF-a \\
\hline 2006 & Pini et al. [61] & $\begin{array}{l}\text { No significant difference in the inflammatory response generated by LPS and concanavalin A administration to } \\
\text { wild-type and adiponectin KO mice }\end{array}$ \\
\hline 2008 & Teoh et al. [60] & Mouse CLP and thioglycollate-induced peritonitis produces a reduction in survival of adiponectin $\mathrm{KO}$ mice \\
\hline 2008 & Pini et al. [62] & $\begin{array}{l}\text { Reduction in circulating adiponectin levels during acute inflammation secondary to zymosan-induced peritonitis in } \\
\text { wild-type mice. Adiponectin does not appear to influence the inflammatory response }\end{array}$ \\
\hline 2009 & Uji et al. [56] & $\begin{array}{l}\text { Mouse CLP model showed adiponectin KO mice are more susceptible to polymicrobial sepsis; higher circulating } \\
\text { endotoxin in adiponectin KO mice; PPAR- } y \text { administration prior to CLP improved mortality in wild type, but not } \\
\text { adiponectin KO mice }\end{array}$ \\
\hline 2009 & Leuwer et al. [80] & $\begin{array}{l}\text { Following injection of LPS in mice, adiponectin mRNA levels fell in white adipose tissue (epididymal, perirenal and } \\
\text { subcutaneous), MCP-1 and IL-6 mRNA rose in all three depots and TNF-a mRNA rose in epididymal and perirenal sites }\end{array}$ \\
\hline 2010 & Uji et al. [57] & $\begin{array}{l}\text { Adiponectin KO and wild-type mice were subjected to CLP. KO mice showed higher circulating levels of pro- } \\
\text { inflammatory cytokines and greater evidence of hepatic injury than wild-type mice }\end{array}$ \\
\hline
\end{tabular}

CLP, caecal ligation and perforation; KO, knockout; LPS, lipopolysaccharidase; MCP-1, monocyte chemoattractant protein-1; PPAR, peroxisome proliferator-activated receptor.

effects of adiponectin were not evident. There were no differences in glucose concentrations or high-density lipoprotein cholesterol levels between the two groups. Rosiglitazone improved mortality only in the wild-type mice, not KO mice, and cytokine levels were not presented in this subgroup. It is likely, therefore, that the beneficial effects of adiponectin on mortality may operate through pathways other than its anti-inflammatory effects.

Not all studies support an anti-inflammatory role for adiponectin. A significant reduction in survival of adiponectin-gene deficient mice was found following CLP, as well as a greater influx of peritoneal neutrophils in these mice following thioglycollate-induced peritonitis [60]. However, the administration of recombinant trimeric adiponectin did not significantly attenuate VCAM and ICAM expression in thioglycollate-challenged adiponectin $\mathrm{KO}$ mice, thus raising questions about its antiinflammatory beneficial role [60]. The improved survival in wild-type mice in this study compared to the $\mathrm{KO}$ mice raises the possibility that adiponectin may provide a survival benefit through alternative, as yet unknown mechanisms.

Another study arguing against an anti-inflammatory role for adiponectin in sepsis is that of Pini and colleagues [61]. They failed to find a difference in the inflammatory response generated by high-dose LPS or concanavalin A administration in adiponectin $\mathrm{KO}$ mice compared with wild type. This lack of positive findings was suggested to be due to the particular strain of adiponectin $\mathrm{KO}$ mice used in the study.

A murine study investigating the role of adipokines in mice exposed to zymosan, a cell wall product of yeast, showed a significant decrease in serum adiponectin during zymosan-induced peritonitis in wild-type mice. The role of adiponectin in the inflammatory process did not appear significant, however, with adiponectin $\mathrm{KO}$ mice actually demonstrating a minor reduction in their peritoneal inflammatory cell infiltrate, and no significant changes in circulating cytokine levels when compared to wild-type mice [62].

The data from animal trials are summarised in Table 2.

\section{Human studies}

Limited human studies of adiponectin in critical illness exist. Lower levels of adiponectin have been found in critically ill patients [58,63-65]. Additionally, Venkatesh and colleagues [64] described a strong association between plasma cortisol and adiponectin, an inverse correlation between plasma C-reactive protein and adiponectin, as well as a linear response between sickness severity and plasma adiponectin. Levels of C-reactive protein in plasma and adipose tissue negatively correlate with adiponectin $[64,66,67]$.

A recent study of patients with acute respiratory failure showed that increased plasma adiponectin levels measured within 48 hours of respiratory failure are associated with mortality [68].

In a study of paediatric patients with sepsis, increased levels of HMW adiponectin were found in the septic shock cohort on day 1 and the plasma levels correlated with risk of mortality scores. This was associated with an increase in PPAR- $\gamma$ activity in peripheral blood mononuclear cells [69].

The human data are summarised in Table 3.

\section{Modulation of adiponectin in critical illness}

Given the abundance of data supporting the beneficial role of adiponectin as a modulator of inflammation, the question arises whether this will play a role in critical illness. Several lines of evidence point to this. Firstly, serum adiponectin concentrations are inversely 
Table 3. Data compiled from human studies in inflammation and sepsis

\begin{tabular}{|c|c|c|}
\hline Year & Reference & Data \\
\hline 2000 & Yokota et al. [34] & $\begin{array}{l}\text { In vitro studies of human myeloid cell lines show that adiponectin is a negative regulator of myelomonocytic } \\
\text { progenitor growth and downregulates the inflammatory response }\end{array}$ \\
\hline 2003 & Keller et al. [54] & $\begin{array}{l}\text { Following induction of endotoxaemia in healthy humans, there was no significant alteration in adiponectin levels } \\
\text { (healthy subjects } n=23: 4 \text { females, } 19 \text { males) }\end{array}$ \\
\hline 2006 & Tsuchihashi et al. [59] & $\begin{array}{l}\text { In vitro studies of recombinant human adiponectin and reconstituted LPS show that adiponectin binds LPS and } \\
\text { suppresses LAL }\end{array}$ \\
\hline 2007 & Anderson et al. [55] & $\begin{array}{l}\text { No significant alteration in adiponectin levels in endotoxaemia, but downregulation of adiponectin receptor mRNA } \\
\text { in white cells (healthy subjects } n=20,50 \% \text { male) }\end{array}$ \\
\hline 2009 & Jernås et al. [63] & Lower levels of adiponectin during intensive care stay compared with recovery (subarachnoid haemorrhage $n=8$ ) \\
\hline 2009 & Venkatesh et al. [64] & $\begin{array}{l}\text { Lower levels of adiponectin in critically ill cohort, with a strong association between plasma cortisol and adiponectin } \\
\text { and an inverse correlation between adiponectin and CRP (critically ill } n=20 \text {; historical controls } n=16 \text { ) }\end{array}$ \\
\hline 2009 & Langouche et al. [65] & $\begin{array}{l}\text { Lower levels of circulating adiponectin in ICU patients on admission; these levels increased to normal reference } \\
\text { values during the ICU stay. Intensive insulin therapy increased the rise of adiponectin over time in ICU. Critically ill } \\
n=318 \text {, healthy subjects } n=22 \text {, acutely stressed subjects } n=22\end{array}$ \\
\hline 2010 & Kaplan et al. [69] & $\begin{array}{l}\text { Increased levels of HMW adiponectin on day } 1 \text { in paediatric septic shock cohort (SIRS/sepsis } n=22 \text {, septic shock } \\
n=25 \text {, control } n=27 \text { ) }\end{array}$ \\
\hline 2010 & Hillenbrand et al. [58] & $\begin{array}{l}\text { Lower levels of adiponectin in septic patients with negative correlation with SOFA scores (septic shock } n=33 \text {, } \\
\text { control (blood donors) } n=60 \text {, morbidly obese } n=37 \text { ) }\end{array}$ \\
\hline 2010 & Walkey et al. [68] & Higher levels of adiponectin at baseline associated with increased 28-day mortality (acute respiratory failure $n=175$ ) \\
\hline
\end{tabular}

associated with the degree of inflammatory response in both cardiovascular disease and critical illness [59,70]. Secondly, a number of studies have reported low levels of adiponectin in critical illness [64]. Hypoadiponectinaemia is also associated with impaired endothelium-dependent vasorelaxation [71]. Data in patients with viral infections and human experimental endotoxaemia suggest altered release patterns of adiponectin in these states [54,72]. The biochemical features of critical illness, that is, hyperglycaemia and cytokinaemia, are also biomarkers for hypoadiponectinaemia. Finally, the increasing numbers of patients with an elevated body mass index and obesity being admitted to intensive care units also raises the prospect of adiponectin playing a role in their underlying pathophysiology. Based on the above set of hypotheses, one could advance the argument that modulation of adiponectin in critical illness may lead to improved inflammatory response, improved glucose tolerance and reduced vasopressor requirement.

It therefore leads to the next question of whether adiponectin levels can be modulated. Despite recombinant adiponectin being widely used in the research setting, there are factors that make the production and therapeutic administration of adiponectin challenging. Full-length adiponectin is a complex molecule that undergoes significant posttranslational modifications, circulates in very high concentrations and has a short plasma half-life [73].

An alternative option is the development of therapeutic agents that modulate and enhance expression and secretion of adiponectin from human cells [73]. Thiazolidinediones are high-affinity ligands for PPAR- $\gamma$ [74] and have strong insulin-sensitising effects [75]. They enhance the expression of adiponectin mRNA within adipocytes [52] and increase the plasma concentration of adiponectin, with a specific increase in the HMW component [76]. It has recently been shown that thiazolidinediones may result in increased secretion of HMW adiponectin from adipocytes, producing the elevated circulating levels [77]. Treatment with fenofibrate results in an increase in serum HMW adiponectin [78], as does niacin therapy [79], despite neither therapies showing an improvement in insulin sensitivity.

Another possibility to modulate levels would be to manipulate the clearance of adiponectin. Adiponectin is ultimately cleared by the liver, but little else is understood about clearance mechanisms [12]. The method of clearance may differ between each molecular weight isoform. Large amounts of adiponectin are continually produced, but it has a relatively short half-life, suggesting that clearance pathways must play a very significant role in controlling circulating levels.

\section{Conclusion}

Adiponectin is a newly described hormone that has a wide range of physiological and metabolic effects. It also appears to be cardioprotective and involved in modulating the inflammatory response. Its role in systemic inflammation and critical illness is not well-defined and 
warrants further investigation. Several questions remain. In critical illness, is survival influenced by baseline adiponectin levels, and would the ability to increase adiponectin and/or the HMW component via either altered expression, altered secretion from the fat cell or altered clearance confer prognostic significance? These questions will need to be examined in future studies.

\section{Key messages}

- Adiponectin is an adipokine with insulin-sensitising and vascular-protective properties.

- Adiponectin also has anti-inflammatory properties.

- Preliminary data suggest low levels of adiponectin in critical illness.

- The significance of these observations needs further elucidation.

- The various therapeutic options to raise circulating levels are discussed.

\section{Abbreviations}

$\mathrm{CLP}$, caecal ligation and perforation; HMW, high-molecular weight; ICAM, intercellular adhesion molecule; IL, interleukin; KO, knockout; LPS, lipopolysaccharidase; NF, nuclear factor; NK, natural killer; PPAR, peroxisome proliferator-activated receptor; TNF, tumour necrosis factor; VCAM, vascular cell adhesion molecule.

\section{Competing interests}

The authors declare that they have no competing interests.

\section{Authors' contributions}

KR was responsible for manuscript preparation and drafting and revision of the manuscript. JP aided in the drafting of the manuscript. BV conceived of the manuscript and aided in the drafting and design of the manuscript. All authors read and approved the final manuscript.

\section{Author details}

IIntensive Care Unit, Wesley Hospital, 451 Coronation Drive, Auchenflower, Brisbane, Queensland, Australia. ${ }^{2}$ Mater Medical Research Institute, Level 3, Aubigny Place, South Brisbane 4101, Queensland, Australia. 3Princess Alexandra Hospital, Intensive Care Unit, Ipswich Rd, Woolloongabba, Brisbane. Australia, 4102. ${ }^{4}$ Wesley Hospital, Intensive Care Unit, 451 Coronation Drive, Auchenflower, Brisbane. Australia, 4066

\section{Published: 20 April 2011}

\section{References}

1. Galic S, Oakhill JS, Steinberg GR: Adipose tissue as an endocrine organ. Mol Cell Endocrinol 2010, 316:129-139.

2. Maury E, Brichard SM: Adipokine dysregulation, adipose tissue inflammation and metabolic syndrome. Mol Cell Endocrinol 2010, 314:1-16.

3. Scherer PE, Williams S, Fogliano M, Baldini G, Lodish HF: A novel serum protein similar to $\mathrm{C} 1 \mathrm{q}$, produced exclusively in adipocytes. $J$ Bio/ Chem 1995, 270:26746-26749.

4. Arita Y, Kihara S, Ouchi N, Takahashi M, Maeda K, Miyagawa J, Hotta K, Shimomura I, Nakamura T, Miyaoka K, Kuriyama H, Nishida M, Yamashita S, Okubo K, Matsubara K, Muraguchi M, Ohmoto Y, Funahashi T, Matsuzawa Y: Paradoxical decrease of an adipose-specific protein, adiponectin, in obesity. Biochem Biophys Res Commun 1999, 257:79-83.

5. Whitehead JP, Richards AA, Hickman IJ, Macdonald GA, Prins JB: Adiponectin - a key adipokine in the metabolic syndrome. Diabetes Obes Metab 2006, 8:264-280.

6. Takahashi M, Arita Y, Yamagata K, Matsukawa Y, Okutomi K, Horie M, Shimomura I, Hotta K, Kuriyama H, Kihara S, Nakamura T, Yamashita S, Funahashi T, Matsuzawa Y: Genomic structure and mutations in adiposespecific gene, adiponectin. Int J Obes Relat Metab Disord 2000, 24:861-868.

7. Combs TP, Berg AH, Rajala MW, Klebanov S, Iyengar P, Jimenez-Chillaron JC,
Patti ME, Klein SL, Weinstein RS, Scherer PE: Sexual differentiation, pregnancy, calorie restriction, and aging affect the adipocyte-specific secretory protein adiponectin. Diabetes 2003, 52:268-276.

8. Nishizawa H, Shimomura I, Kishida K, Maeda N, Kuriyama H, Nagaretani H, Matsuda M, Kondo H, Furuyama N, Kihara S, Nakamura T, Tochino Y, Funahashi T, Matsuzawa Y: Androgens decrease plasma adiponectin, an insulinsensitizing adipocyte-derived protein. Diabetes 2002, 51:2734-2741.

9. Saito K, Tobe T, Minoshima S, Asakawa S, Sumiya J, Yoda M, Nakano Y, Shimizu $\mathrm{N}$, Tomita M: Organization of the gene for gelatin-binding protein (GBP28). Gene 1999, 229:67-73.

10. Simpson F, Whitehead JP: Adiponectin - it's all about the modifications. Int J Biochem Cell Biol, 42:785-788.

11. Liu M, Liu F: Transcriptional and post-translational regulation of adiponectin. Biochem J 2009, 425:41-52.

12. Halberg N, Schraw TD, Wang ZV, Kim J-Y, Yi J, Hamilton MP, Luby-Phelps K, Scherer PE: Systemic fate of the adipocyte-derived factor adiponectin. Diabetes 2009, 58:1961-1970.

13. Komura N, Kihara S, Sonoda M, Maeda N, Tochino Y, Funahashi T, Shimomura I: Increment and impairment of adiponectin in renal failure. Cardiovasc Res 2010, 86:471-477.

14. Shen YY, Charlesworth JA, Kelly JJ, Peake PW: The effect of renal transplantation on adiponectin and its isoforms and receptors. Metabolism 2007, 56:1201-1208.

15. Yamauchi T, Kamon J, Ito Y, Tsuchida A, Yokomizo T, Kita S, Sugiyama T, Miyagishi M, Hara K, Tsunoda M, Murakami K, Ohteki T, Uchida S, Takekawa S, Waki H, Tsuno NH, Shibata Y, Terauchi Y, Froguel P, Tobe K, Koyasu S, Taira K, Kitamura T, Shimizu T, Nagai R, Kadowaki T: Cloning of adiponectin receptors that mediate antidiabetic metabolic effects. Nature 2003, 423:762-769.

16. Yamauchi T, Nio Y, Maki T, Kobayashi M, Takazawa T, Iwabu M, Okada-Iwabu M, Kawamoto S, Kubota N, Kubota T, Ito Y, Kamon J, Tsuchida A, Kumagai K, Kozono H, Hada Y, Ogata H, Tokuyama K, Tsunoda M, Ide T, Murakami K, Awazawa M, Takamoto I, Froguel P, Hara K, Tobe K, Nagai R, Ueki K, Kadowaki T: Targeted disruption of AdipoR1 and AdipoR2 causes abrogation of adiponectin binding and metabolic actions. Nat Med 2007, 13:332-339.

17. Hug C, Wang J, Ahmad NS, Bogan JS, Tsao TS, Lodish HF: T-cadherin is a receptor for hexameric and high-molecular-weight forms of Acrp30/ adiponectin. Proc Natl Acad Sci U S A 2004, 101:10308-10313.

18. Yoon MJ, Lee GY, Chung J-J, Ahn YH, Hong SH, Kim JB: Adiponectin increases fatty acid oxidation in skeletal muscle cells by sequential activation of AMP-activated protein kinase, p38 mitogen-activated protein kinase, and peroxisome proliferator-activated receptor alpha. Diabetes 2006, 55:2562-2570.

19. Yamauchi T, Kamon J, Minokoshi Y, Ito Y, Waki H, Uchida S, Yamashita S, Noda M, Kita S, Ueki K, Eto K, Akanuma Y, Froguel P, Foufelle F, Ferre P, Carling D, Kimura S, Nagai R, Kahn BB, Kadowaki T: Adiponectin stimulates glucose utilization and fatty-acid oxidation by activating AMP-activated protein kinase. Nat Med 2002, 8:1288-1295.

20. Joshi MB, Philippova M, Ivanov D, Allenspach R, Erne P, Resink TJ: T-cadherin protects endothelial cells from oxidative stress-induced apoptosis. FASEB $J$ 2005, 19:1737-1739.

21. Takeuchi T, Adachi Y, Ohtsuki Y, Furihata M: Adiponectin receptors, with special focus on the role of the third receptor, T-cadherin, in vascular disease. Med Mol Morphol 2007, 40:115-120.

22. Ziemke F, Mantzoros CS: Adiponectin in insulin resistance: lessons from translational research. Am J Clin Nutr 2010, 91:258S-261S.

23. Hu E, Liang P, Spiegelman BM: AdipoQ is a novel adipose-specific gene dysregulated in obesity. J Biol Chem 1996, 271:10697-10703.

24. Maeda N, Shimomura I, Kishida K, Nishizawa H, Matsuda M, Nagaretani H, Furuyama N, Kondo H, Takahashi M, Arita Y, Komuro R, Ouchi N, Kihara S, Tochino Y, Okutomi K, Horie M, Takeda S, Aoyama T, Funahashi T, Matsuzawa $Y$ : Diet-induced insulin resistance in mice lacking adiponectin/ACRP30. Nat Med 2002, 8:731-737.

25. Han SH, Sakuma I, Shin EK, Koh KK: Antiatherosclerotic and anti-insulin resistance effects of adiponectin: basic and clinical studies. Prog Cardiovasc Dis, 52:126-140.

26. Hara K, Horikoshi M, Yamauchi T, Yago H, Miyazaki O, Ebinuma H, Imai Y, Nagai $\mathrm{R}$, Kadowaki T: Measurement of the high-molecular weight form of adiponectin in plasma is useful for the prediction of insulin resistance and metabolic syndrome. Diabetes Care 2006, 29:1357-1362.

27. Hung J, McQuillan BM, Thompson PL, Beilby JP: Circulating adiponectin levels associate with inflammatory markers, insulin resistance and 
metabolic syndrome independent of obesity. Int J Obes 2008, 32:772-779.

28. Kaser S, Tatarczyk T, Stadlmayr A, Ciardi C, Ress C, Tschoner A, Sandhofer A, Paulweber B, Ebenbichler CF, Patsch JR: Effect of obesity and insulin sensitivity on adiponectin isoform distribution. Eur J Clin Invest 2008, 38:827-834.

29. Rovin BH, Song H, Hebert LA, Nadasdy T, Nadasdy G, Birmingham DJ, Yung Yu C, Nagaraja HN: Plasma, urine, and renal expression of adiponectin in human systemic lupus erythematosus. Kidney Int 2005, 68:1825-1833.

30. Moriconi N, Kraenzlin M, Muller B, Keller U, Nusbaumer CP, Stohr S, Tamm M, Puder JJ: Body composition and adiponectin serum concentrations in adult patients with cystic fibrosis. J Clin Endocrinol Metab 2006, 91:1586-1590

31. Karmiris K, Koutroubakis IE, Xidakis C, Polychronaki M, Voudouri T, Kouroumalis EA: Circulating levels of leptin, adiponectin, resistin, and ghrelin in inflammatory bowel disease. Inflamm Bowel Dis 2006, 12:100-105.

32. Otero M, Lago R, Gomez R, Lago F, Dieguez C, Gomez-Reino JJ, Gualillo O: Changes in plasma levels of fat-derived hormones adiponectin, leptin, resistin and visfatin in patients with rheumatoid arthritis. Ann Rheum Dis 2006, 65:1198-1201

33. Pang TTL, Narendran P: The distribution of adiponectin receptors on human peripheral blood mononuclear cells. Ann N Y Acad Sci 2008, 1150:143-145.

34. Yokota T, Oritani K, Takahashi I, Ishikawa J, Matsuyama A, Ouchi N, Kihara S, Funahashi T, Tenner AJ, Tomiyama Y, Matsuzawa Y: Adiponectin, a new member of the family of soluble defense collagens, negatively regulates the growth of myelomonocytic progenitors and the functions of macrophages. Blood 2000, 96:1723-1732.

35. Ouchi N, Kihara S, Arita Y, Nishida M, Matsuyama A, Okamoto Y, Ishigami M, Kuriyama H, Kishida K, Nishizawa H, Hotta K, Muraguchi M, Ohmoto Y, Yamashita S, Funahashi T, Matsuzawa Y: Adipocyte-derived plasma protein, adiponectin, suppresses lipid accumulation and class A scavenger receptor expression in human monocyte-derived macrophages. Circulation 2001, 103:1057-1063.

36. Kumada M, Kihara S, Ouchi N, Kobayashi H, Okamoto Y, Ohashi K, Maeda K, Nagaretani H, Kishida K, Maeda N, Nagasawa A, Funahashi T, Matsuzawa Y: Adiponectin specifically increased tissue inhibitor of metalloproteinase- 1 through interleukin-10 expression in human macrophages. Circulation 2004, 109:2046-2049.

37. Ouchi N, Kihara S, Arita Y, Maeda K, Kuriyama H, Okamoto Y, Hotta K, Nishida M, Takahashi M, Nakamura T, Yamashita S, Funahashi T, Matsuzawa Y: Novel modulator for endothelial adhesion molecules : adipocyte-derived plasma protein adiponectin. Circulation 1999, 100:2473-2476.

38. Yamaguchi N, Argueta JG, Masuhiro Y, Kagishita M, Nonaka K, Saito T, Hanazawa S, Yamashita Y: Adiponectin inhibits Toll-like receptor familyinduced signaling. FEBS Lett 2005, 579:6821-6826.

39. Magalang UJ, Rajappan R, Hunter MG, Kutala VK, Kuppusamy P, Wewers MD, Marsh CB, Parinandi NL: Adiponectin inhibits superoxide generation by human neutrophils. Antioxid Redox Signal 2006, 8:2179-2186.

40. Waki H, Yamauchi T, Kamon J, Kita S, Ito Y, Hada Y, Uchida S, Tsuchida A, Takekawa S, Kadowaki T: Generation of globular fragment of adiponectin by leukocyte elastase secreted by monocytic cell line THP-1. Endocrinology 2005, 146:790-796

41. Tsao T-S, Murrey HE, Hug C, Lee DH, Lodish HF: Oligomerization statedependent activation of NF-kB signaling pathway by adipocyte complement-related protein of $30 \mathrm{kDa}$ (Acrp30). J Biol Chem 2002, 277:29359-29362

42. Tomizawa A, Hattori Y, Kasai $\mathrm{K}$ : Induction of gene expression in response to globular adiponectin in vascular endothelial cells. Life Sci 2009, 85:457-461.

43. Tang C-H, Chiu Y-C, Tan T-W, Yang R-S, Fu W-M: Adiponectin enhances IL-6 production in human synovial fibroblast via an AdipoR1 receptor, AMPK, p38, and NF-\{kappa\}B pathway. J Immunol 2007, 179:5483-5492.

44. Wanninger J, Neumeier M, Weigert J, Bauer S, Weiss TS, Schäffler A, Krempl C, Bleyl C, Aslanidis C, Schölmerich J, Buechler C: Adiponectin-stimulated CXCL8 release in primary human hepatocytes is regulated by ERK1/ERK2, p38 MAPK, NF-\{kappa\}B, and STAT3 signaling pathways. Am J Physiol Gastrointest Liver Physiol 2009, 297:G611-618.

45. Ajuwon KM, Spurlock ME: Adiponectin inhibits LPS-induced NF-\{kappa\}B activation and IL-6 production and increases PPAR\{gamma\}2 expression in adipocytes. Am J Physiol Regul Integr Comp Physiol 2005, 288:R1220-1225.

46. Ouchi N, Kihara S, Arita Y, Okamoto Y, Maeda K, Kuriyama H, Hotta K, Nishida M, Takahashi M, Muraquchi M, Ohmoto Y, Nakamura T, Yamashita S, Funahashi
T, Matsuzawa Y: Adiponectin, an adipocyte-derived plasma protein, inhibits endothelial NF-kappaB signaling through a CAMP-dependent pathway. Circulation 2000, 102:1296-1301.

47. Wulster-Radcliffe MC, Ajuwon KM, Wang J, Christian JA, Spurlock ME: Adiponectin differentially regulates cytokines in porcine macrophages. Biochem Biophys Res Commun 2004, 316:924-929.

48. Kim KY, Kim JK, Han SH, Lim JS, Kim KI, Cho DH, Lee MS, Lee JH, Yoon DY, Yoon SR, Chung JW, Choi I, Kim E, Yang Y: Adiponectin is a negative regulator of NK cell cytotoxicity. J Immunol 2006, 176:5958-5964.

49. Hattori Y, Nakano Y, Hattori S, Tomizawa A, Inukai K, Kasai K: High molecular weight adiponectin activates AMPK and suppresses cytokine-induced NF-kappaB activation in vascular endothelial cells. FEBS Lett 2008, 582:1719-1724.

50. Bruun JM, Lihn AS, Verdich C, Pedersen SB, Toubro S, Astrup A, Richelsen B: Regulation of adiponectin by adipose tissue-derived cytokines: in vivo and in vitro investigations in humans. Am J Physiol Endocrinol Metab 2003, 285:E527-533.

51. Kern PA, Di Gregorio GB, Lu T, Rassouli N, Ranganathan G: Adiponectin expression from human adipose tissue: relation to obesity, insulin resistance, and tumor necrosis factor-alpha expression. Diabetes 2003, 52:1779-1785.

52. Maeda N, Takahashi M, Funahashi T, Kihara S, Nishizawa H, Kishida K Nagaretani H, Matsuda M, Komuro R, Ouchi N, Kuriyama H, Hotta K, Nakamura T, Shimomura I, Matsuzawa Y: PPARgamma ligands increase expression and plasma concentrations of adiponectin, an adipose-derived protein. Diabetes 2001, 50:2094-2099.

53. Kappes A, Loffler G: Influences of ionomycin, dibutyryl-cycloAMP and tumour necrosis factor-alpha on intracellular amount and secretion of apM1 in differentiating primary human preadipocytes. Horm Metab Res 2000, 32:548-554

54. Keller P, Moller K, Krabbe KS, Pedersen BK: Circulating adiponectin levels during human endotoxaemia. Clin Exp Immunol 2003, 134:107-110.

55. Anderson PD, Mehta NN, Wolfe ML, Hinkle CC, Pruscino L, Comiskey LL, Tabita-Martinez J, Sellers KF, Rickels MR, Ahima RS, Reilly MP: Innate immunity modulates adipokines in humans. J Clin Endocrinol Metab 2007, 92:2272-2279.

56. Uji Y, Yamamoto H, Tsuchihashi H, Maeda K, Funahashi T, Shimomura I, Shimizu T, Endo Y, Tani T: Adiponectin deficiency is associated with severe polymicrobial sepsis, high inflammatory cytokine levels, and high mortality. Surgery 2009, 145:550-557.

57. Uji Y, Yamamoto H, Maeda K, Tsuchihashi H, Akabori H, Shimizu T, Endo Y, Shimomura I, Tani T: Adiponectin deficiency promotes the production of inflammatory mediators while severely exacerbating hepatic injury in mice with polymicrobial sepsis. J Surg Res 2010, 161:301-311.

58. Hillenbrand A, Knippschild U, Weiss M, Schrezenmeier H, Henne-Bruns D, Huber-Lang M, Wolf AM: Sepsis induced changes of adipokines and cytokines - septic patients compared to morbidly obese patients. BMC Surg 2010, 10:26.

59. Tsuchihashi H, Yamamoto H, Maeda K, Ugi S, Mori T, Shimizu T, Endo Y, Hanasawa K, Tani T: Circulating concentrations of adiponectin, an endogenous lipopolysaccharide neutralizing protein, decrease in rats with polymicrobial sepsis. J Surg Res 2006, 134:348-353.

60. Teoh H, Quan A, Bang KW, Wang G, Lovren F, Vu V, Haitsma JJ, Szmitko PE, Al-Omran M, Wang CH, Gupta M, Peterson MD, Zhang H, Chan L, Freedman J, Sweeney G, Verma S: Adiponectin deficiency promotes endothelial activation and profoundly exacerbates sepsis-related mortality. Am J Physiol Endocrinol Metab 2008, 295:E658-664.

61. Pini M, Sennello JA, Chan L, Fantuzzi G: Adiponectin deficiency does not affect the inflammatory response to endotoxin or concanavalin a in mice. Endocrinology 2006, 147:5019-5022.

62. Pini M, Gove ME, Sennello JA, van Baal JW, Chan L, Fantuzzi G: Role and regulation of adipokines during zymosan-induced peritoneal inflammation in mice. Endocrinology 2008, 149:4080-4085.

63. Jernas M, Olsson B, Sjoholm K, Sjogren A, Rudemo M, Nellgard B, Carlsson LM, Sjostrom CD: Changes in adipose tissue gene expression and plasma levels of adipokines and acute-phase proteins in patients with critical illness. Metabolism 2009, 58:102-108.

64. Venkatesh B, Hickman I, Nisbet J, Cohen J, Prins J: Changes in serum adiponectin concentrations in critical illness: a preliminary investigation. Crit Care 2009, 13:R105.

65. Langouche L, Vander Perre S, Frystyk J, Flyvbjerg A, Hansen TK, Van den 
Berghe G: Adiponectin, retinol-binding protein 4, and leptin in protracted critical illness of pulmonary origin. Crit Care 2009, 13:R112.

66. Ouchi N, Kihara S, Funahashi T, Nakamura T, Nishida M, Kumada M, Okamoto Y, Ohashi K, Nagaretani H, Kishida K, Nishizawa H, Maeda N, Kobayashi H, Hiraoka H, Matsuzawa Y: Reciprocal association of C-reactive protein with adiponectin in blood stream and adipose tissue. Circulation 2003, 107:671-674.

67. Engeli S, Feldpausch M, Gorzelniak K, Hartwig F, Heintze U, Janke J, Mohlig M, Pfeiffer AF, Luft FC, Sharma AM: Association between adiponectin and mediators of inflammation in obese women. Diabetes 2003, 52:942-947.

68. Walkey AJ, Rice TW, Konter J, Ouchi N, Shibata R, Walsh K, deBoisblanc BP, Summer R: Plasma adiponectin and mortality in critically ill subjects with acute respiratory failure. Crit Care Med 2010, 38:2329-2334.

69. Kaplan JM, Denenberg A, Monaco M, Nowell M, Wong H, Zingarelli B: Changes in peroxisome proliferator-activated receptor-gamma activity in children with septic shock. Intensive Care Med 2010, 36:123-130.

70. Ouedraogo R, Gong Y, Berzins B, Wu X, Mahadev K, Hough K, Chan L, Goldstein BJ, Scalia R: Adiponectin deficiency increases leukocyteendothelium interactions via upregulation of endothelial cell adhesion molecules in vivo. $J$ Clin Invest 2007, 117:1718-1726.

71. Ouchi N, Ohishi M, Kihara S, Funahashi T, Nakamura T, Nagaretani H, Kumada M, Ohashi K, Okamoto Y, Nishizawa H, Kishida K, Maeda N, Nagasawa A, Kobayashi H, Hiraoka H, Komai N, Kaibe M, Rakugi H, Ogihara T, Matsuzawa Y: Association of hypoadiponectinemia with impaired vasoreactivity. Hypertension 2003, 42:231-234.

72. Palmer C, Hampartzoumian T, Lloyd A, Zekry A: A novel role for adiponectin in regulating the immune responses in chronic hepatitis $C$ virus infection. Hepatology 2008, 48:374-384.

73. Shetty S, Kusminski CM, Scherer PE: Adiponectin in health and disease: evaluation of adiponectin-targeted drug development strategies. Trends Pharmacol Sci 2009, 30:234-239
74. Lehmann JM, Moore LB, Smith-Oliver TA, Wilkison WO, Willson TM, Kliewer SA An antidiabetic thiazolidinedione is a high affinity ligand for peroxisome proliferator-activated receptor gamma (PPAR gamma). J Biol Chem 1995, 270:12953-12956.

75. Fujiwara T, Yoshioka S, Yoshioka T, Ushiyama I, Horikoshi H: Characterization of new oral antidiabetic agent CS-045. Studies in KK and ob/ob mice and Zucker fatty rats. Diabetes 1988, 37:1549-1558.

76. Qurashi S, Mynarcik DC, McNurlan MA, Ahn H, Ferris R, Gelato MC: Importance of the high-molecular-mass isoform of adiponectin in improved insulin sensitivity with rosiglitazone treatment in HIV disease. Clin Sci (Lond) 2008, 115:197-202.

77. Phillips SA, Kung J, Ciaraldi TP, Choe C, Christiansen L, Mudaliar S, Henry RR: Selective regulation of cellular and secreted multimeric adiponectin by antidiabetic therapies in humans. Am J Physiol Endocrinol Metab 2009, 297:E767-773.

78. Oki K, Koide J, Nakanishi S, Nakashima R, Yamane K: Fenofibrate increases high molecular weight adiponectin in subjects with hypertriglyceridemia. Endocr J 2007, 54:431-435,

79. Westphal S, Luley C: Preferential increase in high-molecular weight adiponectin after niacin. Atherosclerosis 2008, 198:179-183.

80. Leuwer M, Welters I, Marx G, Rushton A, Bao H, Hunter L, Trayhurn P: Endotoxaemia leads to major increases in inflammatory adipokine gene expression in white adipose tissue of mice. Pflugers Arch 2009, 457:731-741.

doi:10.1186/cc10021

Cite this article as: Robinson K, et al.: Clinical review: Adiponectin biology and its role in inflammation and critical illness. Critical Care 2011, 15:221. 